\title{
Performance of Blue-Yellow Screening Test for Antimicrobial Detection in Ovine Milk
}

\author{
B. Linage, ${ }^{\star}$ C. Gonzalo, ${ }^{\star 1}$ J. A. Carriedo, ${ }^{*}$ J. A. Asensio,† M. A. Blanco,† L. F. De La Fuente, ${ }^{*}$ \\ and F. San Primitivo* \\ *Departamento de Producción Animal, Facultad de Veterinaria, Universidad de León, 24071 León, Spain \\ †Consorcio de Promoción del Ovino, 49630-Villalpando, Zamora, Spain
}

\begin{abstract}
Drug residues in milk are important because of public health and industrial implications. The detection limits of 25 antimicrobial agents were determined by the blueyellow screening method in ovine milk. For each drug, 8 concentrations were tested on 20 ovine milk samples from individual ewes in midlactation. Detection limits determined by means of logistic regression were below European Union maximum residue limits (EU-MRL) for penicillin G (3 to $4 \mu \mathrm{g} / \mathrm{kg}$ ), ceftiofur (96 to $107 \mu \mathrm{g} /$ $\mathrm{kg}$ ), framycetin (720 to $781 \mu \mathrm{g} / \mathrm{kg}$ ), neomycin (915 to $1,084 \mu \mathrm{g} / \mathrm{kg}$ ), and tylosin (44 to $51 \mu \mathrm{g} / \mathrm{kg}$ ). Detection limits for ampicillin (5 to $6 \mu \mathrm{g} / \mathrm{kg}$ ), cloxacillin (33 to 42 $\mu \mathrm{g} / \mathrm{kg}$ ), cefoperazone (73 to $82 \mu \mathrm{g} / \mathrm{kg}$ ), cefalexin (160 to $202 \mu \mathrm{g} / \mathrm{kg}$ ), gentamycin (355 to $382 \mu \mathrm{g} / \mathrm{kg}$ ), streptomycin $(3,063$ to $3,593 \mu \mathrm{g} / \mathrm{kg}$ ), tilmicosin (109 to $131 \mu \mathrm{g} /$ $\mathrm{kg}$ ), erythromycin (444 to $522 \mu \mathrm{g} / \mathrm{kg}$ ), spyramicin $(1,106$ to $1,346 \mu \mathrm{g} / \mathrm{kg}$ ), sulfadimethoxine (101 to $119 \mu \mathrm{g} / \mathrm{kg}$ ), sulfathiazole (122 to $151 \mu \mathrm{g} / \mathrm{kg}$ ), sulfamethazine (309 to $328 \mu \mathrm{g} / \mathrm{kg})$, sulfanilamide $(1,750$ to $2,674 \mu \mathrm{g} / \mathrm{kg})$, tetracycline (233 to $257 \mu \mathrm{g} / \mathrm{kg}$ ), oxytetracycline (398 to 501 $\mu \mathrm{g} / \mathrm{kg}$ ), doxycycline (323 to $419 \mu \mathrm{g} / \mathrm{kg}$ ), chlortetracycline $(3,331$ to $3,989 \mu \mathrm{g} / \mathrm{kg})$, danofloxacin (4.7 to $5.5 \mathrm{mg} / \mathrm{kg})$, enrofloxacin (41 to $46 \mathrm{mg} / \mathrm{kg}$ ), and flumequin (63 to 71 $\mathrm{mg} / \mathrm{kg}$ ) were higher than the EU-MRL. Although the blue-yellow method showed improved sensitivity compared with other tests studied in ovine milk, the performance of screening methods for detecting antimicrobial agents in milk of this species should be improved.
\end{abstract}

Key words: ovine milk, screening test, detection limit, antimicrobial residue

\section{INTRODUCTION}

Ewe milk is used mainly in the production of fermented dairy products, especially cheese. The presence

Received March 29, 2007.

Accepted August 27, 2007.

${ }^{1}$ Corresponding author: c.gonzalo@unileon.es of antimicrobial residues (AR) in milk constitutes a potential hazard for the consumer because of allergic reactions, intestinal dysbiosis, and resistant populations of bacteria in the general population (Allison, 1985; Dewdney et al., 1991). In addition, AR in milk could cause serious technical problems for the dairy industry by inhibiting the bacterial processes involved in the elaboration of cheese and cultured milk products (Mourot and Loussouarn, 1981).

The European Union (EU) determines the limits for the presence of specified veterinary residues in milk. The antimicrobial residues are defined by Council Regulation EEC 2377/90 (EU, 1990), although a number of amendments have subsequently been made to extend the list of agents with maximum residue limits (MRL) established.

Increasing awareness of public health and food safety issues in recent years has lead to a greater interest in milk quality. To determine the presence of AR in cow milk, several rapid screening tests have been developed to test milk on the farm or in milk plants (IDF, 1991); recently, interest in research into AR detection is growing in dairy sheep (Berruga et al., 2003; Yamaki et al., 2004). As intensification of milk production in small ruminants has increased in recent years, the use of antimicrobial substances in dairy ewes has become a usual practice in veterinary medicine to treat mastitis and other diseases. In addition, the shortage of specific commercial formulations for dairy ewes makes it necessary to use antibiotic preparations normally used in cattle, the withdrawal period of which is undefined in ewe's milk. Within an AR testing program in this species, a broad study on AR detection methods is needed to guarantee residue levels in milk below the established EU-MRL. Validation of tests is essential for selection of the most appropriate testing strategies, estimation of predictive values, appropriate test interpretation, and to ensure that testing programs operate as efficiently as possible (Gardner, 1997). The first results obtained from the BRT-AiM (AIM-Analytik in Milch Producktions-und Vertriebs GmbH, Munich, Germany; Althaus et al., 2001; Molina et al., 2003), Delvotest-SP 
(DSM Food Specialities, Delft, the Netherlands; Althaus et al., 2003), and Eclipse-100ov (ZEU-Immunotec, Zaragoza, Spain; Montero, 2004) tests in detecting AR in ovine milk demonstrated low sensitivity and high variability of those methods, particularly for no- $\beta$-lactam AR.

The blue-yellow method (BY) is a broad-spectrum microbial inhibition assay for cow milk AR detection, and it is not well known in countries of the European Union. This simple and easy-to-read screening test gives results within a relatively short period $(<3 \mathrm{~h})$. Results of the BY test are classified visually into 3 categories: "negative," "doubtful," and "positive" compared with reference colors. According to manufacturer's instructions, the detection limits (DL) of this test for some macrolides, aminoglycosides, tetracyclines, and sulfonamides are close to MRL, and an attempt should be made to evaluate the test's performance in ovine milk.

Thus, the evaluation of this method for ovine milk could be of interest in programs for AR detection, and this study should increase the information about the performance of AR detection methods in dairy sheep. The aim of this research was to calculate the BY DL for 25 antimicrobial agents belonging to 6 different families in ovine milk.

\section{MATERIALS AND METHODS}

Individual ewe milk samples $(50 \mathrm{~mL})$ were collected in midlactation from Assaf ewes of the experimental flock located on the farm of the Department of Animal Production, University of León (Spain). The total flock size was 250 lactating ewes, and the selection of ewes for sampling was done randomly. The animals received no pharmacological treatment before the study, and samples corresponded to the morning machine milking $(0800 \mathrm{~h})$. Ewes with atrophic half-udders were excluded from this study. The flock was kept permanently in stalls, and they remained under similar environmental, handling, and feeding conditions. The SCC of bulk tank milk was always $\leq 500 \times 10^{3}$ cells $/ \mathrm{mL}$.

Milk samples were analyzed during the 4-h period after collection by BY test (Charm Sciences Inc., Lawrence, MA), which is a microbial growth inhibition assay intended for use on bulk tank milk and individual animal samples. After the addition of $50 \mu \mathrm{L}$ of milk into single wells containing spores of Geobacillus stearothermophilus var. calidolactis ATCC 10149 strain, plates were incubated at $65^{\circ} \mathrm{C}$ for $2 \mathrm{~h} 45 \mathrm{~min}$. Visual interpretation of results was carried out by comparison with a color table and evaluated as negative, doubtful, or positive.
In accordance with the IDF indications (IDF, 1999), 8 concentrations were prepared for each drug in the proximity of the test detection level. A previous study using dilutions (1:10) between $100 \mathrm{mg} / \mathrm{kg}$ and $0.1 \mu \mathrm{g} /$ $\mathrm{kg}$ was carried out as a first approximation to DL for each antimicrobial agent. For each concentration, 20 replicates were prepared using 20 different antibioticfree milk samples obtained from individual animals. The number of different individual milk samples was 125 (each sample was used to test the 8 concentrations of each drug in 4 different drugs). Samples were collected on the day of testing. The number of antimicrobial agents studied was 25, from 6 antimicrobial families. The list of drugs included 3 penicillins (penicillin G, ampicillin, cloxacillin), 3 cephalosporins (cefoperazone, cephalexin, and ceftiofur), 4 aminoglycosides (gentamycin, neomycin, framycetin, and streptomycin), 4 macrolides (tylosin, tilmicosin, spyramicin, and erythromycin), 4 tetracyclines (tetracycline, doxicycline, oxytetracycline, and chlortetracycline), 4 sulfonamides (sulfadimethoxine, sulfathiazole, sulfamethazine, sulfanilamide), and 3 quinolones (enrofloxacine, flumequine, and danofloxacine). Table 1 summarizes the antimicrobial agents and the concentrations used. These drugs were stored and handled according to the manufacturers' instructions before being used. Drugs were dissolved $(1 \mathrm{mg} / \mathrm{mL}$ ) in water, except ceftiofur (dissolved in Tris- $\mathrm{HCl}, 100 \mathrm{mM}, \mathrm{pH}$ 9); sulfanilamide, tetracycline, chlortetracycline, and oxytetracycline (dissolved in methanol); and erythromycin (dissolved in ethanol). The $\mathrm{pH}$ were adjusted with $\mathrm{KOH}$ or $\mathrm{HCl}$. Final concentrations in milk ( $\mu \mathrm{g} / \mathrm{kg})$ were achieved after serial dilutions in such a way that the volume of the antimicrobial agent solution did not exceed $1 \%$ of the volume of the final solution to be analyzed. In this study, the total number of observations was 4,000 (25 drugs $\times 8$ concentrations $\times 20$ replicates).

Because BY is a method with visual interpretation, reproducibility between observers was studied in 6 antimicrobial drugs, 1 from each antimicrobial family. The 8 concentrations of each antimicrobial agent were tested in 4 different ovine milks, and visual interpretation of results was carried out independently by $3 \mathrm{ob}-$ servers by comparison with a color table. Results were always evaluated as negative, doubtful, or positive. In this study, the total number of different observations was 192 ( 6 drugs $\times 8$ concentrations $\times 4$ milks), which were read by 3 independent observers.

\section{Statistical Analyses}

The DL of antimicrobial agents were estimated by a logistic regression model using the LOGISTIC procedure of SAS (SAS Institute, 1998). For this model, the 
Table 1. Antimicrobial agents and concentrations used for blue-yellow detection limits in ovine milk

\begin{tabular}{|c|c|c|}
\hline $\begin{array}{l}\text { Antimicrobial } \\
\text { class/agent }\end{array}$ & Product number ${ }^{1}$ & Concentrations tested $(\mu \mathrm{g} / \mathrm{kg}$ or $* \mathrm{mg} / \mathrm{kg})$ \\
\hline \multicolumn{3}{|l|}{$\beta$-lactams } \\
\hline Penicillin G & Sigma Pen-Na & $0.5,1,2,3,4,5,6,7$ \\
\hline Ampicillin & Fluka 10045 & $1,2,3,4,5,6,7,8$ \\
\hline Cloxacillin & Fluka 27555 & $5,10,20,30,40,50,60,70$ \\
\hline Cefalexine & Fluka 22238 & $25,50,100,150,200,250,300,350$ \\
\hline Ceftiofur & Riedel de Haën 34001 & $60,70,80,90,100,110,120,130$ \\
\hline Cefoperazone & Fluka 22129 & $40,50,60,70,80,90,100,110$ \\
\hline \multicolumn{3}{|l|}{ Aminoglycosides } \\
\hline Gentamycin & Sigma G-3632 & $200,250,300,350,400,450,500,550$ \\
\hline Neomycin & Fluka 72133 & $600,700,800,900,1,000,1,100,1,200,1,300$ \\
\hline Framycetin & Riedel de Haën 33492 & $300,400,500,600,700,800,900,1,000$ \\
\hline Streptomycin & Fluka 85880 & $1.5,2,2.5,3,3.5,4,4.5,5^{*}$ \\
\hline \multicolumn{3}{|l|}{ Macrolides } \\
\hline Tylosin & Sigma T-6134 & $10,20,30,40,50,60,70,80$ \\
\hline Tilmicosin & Riedel de Haën 33864 & $60,70,80,90,100,150,200,250$ \\
\hline Erythromycin & Fluka 45673 & $100,200,300,400,500,600,700,800$ \\
\hline Spyramicin & Sigma S-9132 & $0.25,0.5,0.75,1,1.25,1.5,1.75,2^{*}$ \\
\hline \multicolumn{3}{|l|}{ Tetracyclines } \\
\hline Tetracycline & Sigma T-3258 & $50,100,150,200,250,300,350,400$ \\
\hline Oxytetracycline & Fluka 75966 & $90,100,200,300,400,500,600,700$ \\
\hline Doxycycline & Fluka 44577 & $50,100,200,300,400,500,600,700$ \\
\hline Chlortetracycline & Sigma C-4881 & $0.5,1,1.5,2,3,4,5,6^{*}$ \\
\hline \multicolumn{3}{|l|}{ Sulfonamides } \\
\hline Sulfadimethoxine & Sigma S-7358 & $60,70,80,90,100,200,250,300$ \\
\hline Sulfathiazole & Sigma S-0127 & $80,90,100,110,120,150,200,220$ \\
\hline Sulfamethazine & Sigma S-5637 & $50,100,200,300,400,500,600,700$ \\
\hline Sulfanilamide & Sigma S-9251 & $0.25,0.5,1,1.5,2,2.5,3,3.5^{*}$ \\
\hline \multicolumn{3}{|l|}{ Quinolones } \\
\hline Danofloxacine & Riedel de Haën 33700 & $1,2,3,4,5,6,7,8^{*}$ \\
\hline Enrofloxacine & Fluka 17849 & $5,10,20,30,40,50,60,70^{*}$ \\
\hline Flumequine & Riedel de Haën 45735 & $20,30,40,50,60,70,80,90^{*}$ \\
\hline
\end{tabular}

${ }^{1}$ Products obtained from Sigma (St. Louis, MO), Fluka (Buchs, Switzerland), and Riedel de Haën (Seelze, Germany).

response was considered as ordinal with 3 possible values, which corresponded to positive, doubtful, and negative results. The logistic regression model used was

$$
\mathrm{L}_{\mathrm{ij}}=\operatorname{logit}\left[\mathrm{P}_{\mathrm{ij}}\right]=\mathrm{a}_{0}+\mathrm{b} \mathrm{AC}_{\mathrm{i}}+\varepsilon_{\mathrm{ij}}
$$

where logit $=$ lineal logistic model; i.e., $\ln \left[\mathrm{P}_{\mathrm{ij}} /\left(1-\mathrm{P}_{\mathrm{ij}}\right)\right]$; $\mathrm{P}_{\mathrm{ij}}=$ probability of positive vs. doubtful + negative results, on the one hand, and positive + doubtful vs. negative results, on the other hand; $\mathrm{AC}=$ antimicrobial concentration; $\mathrm{a}=$ intercept; $\mathrm{b}=$ slope; and $\varepsilon_{\mathrm{ij}}=$ residual error. In this study, 2 intercept coefficients were obtained: $\mathrm{a}_{01}$, for the estimation of frequency of positive vs. doubtful + negative results, and $\mathrm{a}_{02}$, for the estimation of frequency of positive + doubtful vs. negative results. The concordance coefficients were also estimated. This coefficient was applied as rank correlation between observed and predicted results (Althaus et al., 2003). This model included all possible categorical results and provided 2 DL for each antimicrobial agent. The DL of visual interpretation for BY test was estimated as the concentration at which $95 \%$ of results were positive. Sensitivity was defined as the antimicrobial concentration that was detected by BY test.

According to Ortega et al. (1995), reproducibility between observers was evaluated by means of kappa value defined as $(\mathrm{OP}-\mathrm{EP}) /(1-\mathrm{EP})$, where $\mathrm{OP}=$ observed concordance between observers, and $\mathrm{EP}=$ random predicted concordance.

\section{RESULTS AND DISCUSSION}

Concordance of the BY test between observers was very high. Kappa values were $0.99,0.96$, and 0.96 between observers 1 and 2, 1 and 3, and 2 and 3, respectively, when doubtful results were considered as negative; and 0.97, 0.94, and 0.94 when doubtful results were considered as positive.

Table 2 summarizes the statistical and DL values. Two DL values were found for each antimicrobial agent: $\mathrm{DL}_{1}$ for comparison between positive vs. doubtful + negative results, and $\mathrm{DL}_{2}$ for comparison between positive + doubtful vs. negative results. The concordance percentages of logistic regression were high (85.7 to $97.7 \%$; 
Table 2. Summary of logistic regression model and blue-yellow detection limits (DL, ${ }^{1} \mu \mathrm{g} / \mathrm{kg}$ ) of 25 antimicrobials agents studied in ovine milk considering an ordinal response variable

\begin{tabular}{|c|c|c|c|c|c|c|c|}
\hline $\begin{array}{l}\text { Antimicrobial } \\
\text { class/agent }\end{array}$ & $\begin{array}{c}\text { Intercept } 1 \\
\left(\mathrm{a}_{01}\right)\end{array}$ & $\begin{array}{c}\text { Intercept } 2 \\
\left(\mathrm{a}_{02}\right)\end{array}$ & $\begin{array}{l}\text { Slope } \\
\text { (b) }\end{array}$ & $\begin{array}{c}\text { Concordance } \% \\
\text { (c) }\end{array}$ & $\mathrm{DL}_{1}$ & $\mathrm{DL}_{2}$ & $\begin{array}{c}\mathrm{MRL}^{2} \\
(\mu \mathrm{g} / \mathrm{kg})\end{array}$ \\
\hline \multicolumn{8}{|l|}{$\beta$-Lactams } \\
\hline Penicillin G & -17.718 & -14.468 & 4.608 & 97.3 & 4 & 3 & 4 \\
\hline Ampicilin & -14.480 & -12.088 & 3.035 & 96.3 & 6 & 5 & 4 \\
\hline Cloxacillin & -49.295 & -38.358 & 1.232 & 94.5 & 42 & 33 & 30 \\
\hline Cefoperazone & -98.069 & -87.197 & 1.226 & 94.5 & 82 & 73 & 50 \\
\hline Ceftiofur & -44.633 & -39.629 & 0.442 & 97.1 & 107 & 96 & 100 \\
\hline Cefalexin & -49.024 & -38.215 & 0.256 & 89.1 & 202 & 160 & 100 \\
\hline \multicolumn{8}{|l|}{ Aminoglycosides } \\
\hline Gentamycin & -138.600 & -128.600 & 0.370 & 87.4 & 382 & 355 & 100 \\
\hline Framycetin & -27.233 & -24.883 & 0.039 & 97.3 & 781 & 720 & 1,500 \\
\hline Neomycin & -49.557 & -44.293 & 0.048 & 97.7 & 1,084 & 915 & 1,500 \\
\hline Streptomycin & -86.183 & -73.015 & 0.025 & 85.7 & 3,593 & 3,063 & 200 \\
\hline \multicolumn{8}{|l|}{ Macrolides } \\
\hline Tylosin & -13.888 & -11.847 & 0.332 & 96.8 & 51 & 44 & 50 \\
\hline Tilmicosin & -18.263 & -14.659 & 0.162 & 96.3 & 131 & 109 & 50 \\
\hline Erythromycin & -66.479 & -56.120 & 0.133 & 97.5 & 522 & 444 & 40 \\
\hline Spyramycin & -12.405 & -9.670 & 0.011 & 96.0 & 1,346 & 1,106 & 200 \\
\hline \multicolumn{8}{|l|}{ Tetracyclines } \\
\hline Tetracycline & -92.642 & -83.533 & 0.371 & 98.6 & 257 & 233 & 100 \\
\hline Oxytetracycline & -14.351 & -10.796 & 0.034 & 96.8 & 501 & 398 & 100 \\
\hline Doxycycline & -47.667 & -36.014 & 0.121 & 88.8 & 419 & 323 & - \\
\hline Chlortetracycline & -11.262 & -8.918 & 0.004 & 96.9 & 3,989 & 3,331 & 100 \\
\hline \multicolumn{8}{|l|}{ Sulfonamides } \\
\hline Sulfadimethoxine & -22.838 & -18.948 & 0.215 & 95.9 & 119 & 101 & 100 \\
\hline Sulfathiazole & -30.556 & -23.999 & 0.221 & 88.3 & 151 & 122 & 100 \\
\hline Sulfamethazine & -38.625 & -36.271 & 0.127 & 98.3 & 328 & 309 & 100 \\
\hline Sulfanilamide & -13.587 & -7.879 & 0.006 & 94.5 & 2,674 & 1,750 & 100 \\
\hline \multicolumn{8}{|l|}{ Quinolones } \\
\hline Danofloxacine & -18.765 & -15.955 & 0.003 & 97.1 & 5,495 & 4,783 & 30 \\
\hline Enrofloxacine & -83.582 & -73.795 & 0.002 & 84.1 & $46^{3}$ & $41^{3}$ & 100 \\
\hline Flumequine & -12.333 & -10.535 & 0.0002 & 94.4 & $71^{3}$ & $63^{3}$ & 50 \\
\hline
\end{tabular}

${ }^{1} \mathrm{DL}_{1}=$ detection limit for positive vs. doubtful + negative; $\mathrm{DL}_{2}=$ detection limit for positive + doubtful vs. negative.

${ }^{2} \mathrm{MRL}=$ European Union maximum residue limits.

${ }^{3}$ Values in $\mathrm{mg} / \mathrm{kg}$.

Table 2) illustrating the good correlation achieved between observed and predicted results by logistic regression.

The doubtful results should only be considered as positive if the DL of an antimicrobial drug was greater than the MRL, but if the DL was smaller than MRL, then the doubtful results were negative. In addition, the concordance between observers was very high. Clear positive or negative results were easily identified by 3 observers, but some discrepancy between observers was possible for concentrations close to DL. This discrepancy was considered by the model of logistic regression used in the statistical study, in which doubtful results were grouped with positive or negative results. So, 2 DL were obtained showing a sensitivity interval for each antimicrobial agent for any observer. So, the logistic regression considering 2 DL seemed more appropriate than logistic regression based in binary response with 1 DL only (i.e., positive + doubtful vs. negative results) used in other studies (Althaus et al., 2001, 2003).

The coefficient b (slope) of logistic regression is a parameter closely related to the screening test sensitivity for each antimicrobial agent. A smaller b coefficient produced greater DL values and consequently less BY sensitivity for any antimicrobial agent. The lowest $b$ values were for quinolones (0.0002 to 0.003$)$ and the greatest values were for penicillin $\mathrm{G}$ (4.6) and ampicillin (3.03; Table 2).

The $b$ parameter reached greater values for $\beta$-lactams than for the other chemotherapeutics assayed. The DL calculated for penicillin $\mathrm{G}$ (3 to $4 \mu \mathrm{g} / \mathrm{kg}$ ) and ceftiofur (96 to $107 \mu \mathrm{g} / \mathrm{kg}$ ) were similar to or below EU-MRL (4 and $100 \mu \mathrm{g} / \mathrm{kg}$, respectively). The DL for ampicillin (5 to $6 \mu \mathrm{g} / \mathrm{kg}$ ), cloxacillin (33 to $42 \mathrm{~g} / \mathrm{kg}$ ), cefoperazone (73 to $82 \mu \mathrm{g} / \mathrm{kg}$ ), and cefalexin (160 to $202 \mu \mathrm{g} / \mathrm{kg}$ ) were greater than EU-MRL $(4,30,50$, and $100 \mu \mathrm{g} / \mathrm{kg})$. These DL were very similar to found by other authors using 
the BRT, Eclipse-100ov or Delvotest-SP screening tests in ovine milk (Althaus et al., 2001, 2003; Montero, $2004)$, although the DL for penicillin $(1 \mu \mathrm{g} / \mathrm{kg})$ and cephalexin $(40 \mu \mathrm{g} / \mathrm{kg})$ were lower in the Delvotest-SP test (Althaus et al., 2003). $\beta$-Lactams can be effective against gram-positive pathogens and they are frequently used in mastitis therapies for dairy sheep (Marco, 1994; Molina et al., 2003, Linage et al., 2007), so a detection program for $\beta$-lactams in milk has been implemented in the main dairy sheep basins (i.e., Eclipse 100 ov method in Castilla y León, Spain).

Framycetin (720 to $781 \mu \mathrm{g} / \mathrm{kg}$ ) and neomycin (915 to $1,084 \mu \mathrm{g} / \mathrm{kg}$ ) had DL lower than those found by using the Delvotest-SP $(2,600 \mu \mathrm{g} / \mathrm{kg})$, BRT-AiM $(3,700 \mu \mathrm{g} / \mathrm{kg})$, and Eclipse-100ov $(9,100 \mu \mathrm{g} / \mathrm{kg})$ tests for neomycin in ovine milk (Althaus et al., 2003; Molina et al., 2003; Montero, 2004). Results for framycetin using other tests than BY are unknown in ovine milk. In addition, the DL for gentamycin (355 to $382 \mu \mathrm{g} / \mathrm{kg}$ ) and streptomycin $(3,063$ to $3,593 \mu \mathrm{g} / \mathrm{kg})$ were also lower than those obtained by using the Delvotest-SP, BRT-AiM, or Eclipse$100 \mathrm{ov}$ tests $(1,200$ to $1,950 \mu \mathrm{g} / \mathrm{kg}$ for gentamycin, and 6,100 to $10,000 \mu \mathrm{g} / \mathrm{kg}$ for streptomycin; Althaus et al., 2003; Molina et al., 2003; Montero, 2004). Consequently, BY had greater sensitivity than other screening tests for detecting aminoglycosides. Nevertheless, only DL for neomycin and framycetin obtained by BY in ovine milk were lower than EU-MRL $(1,500 \mu \mathrm{g} / \mathrm{kg})$. This screening test is not appropriate, however, for gentamycin (EU-MRL: $100 \mu \mathrm{g} / \mathrm{kg}$ ) or streptomycin (EUMRL: $200 \mu \mathrm{g} / \mathrm{kg}$ ), which showed the lowest $\mathrm{b}$ values (0.37 and 0.03). Neomycin and framycetin are antimicrobial agents used in mastitis treatments (i.e., ewe dry therapies) because of their effectiveness against gramnegative organisms, so the high sensitivity showed for $\mathrm{BY}$ in detecting these drugs must be emphasized.

Within the macrolides, only tylosin (44 to $51 \mu \mathrm{g} / \mathrm{kg}$ ) showed a DL very close to EU-MRL $(50 \mu \mathrm{g} / \mathrm{kg})$, but the DL for tilmicosin (109 to $131 \mu \mathrm{g} / \mathrm{kg}$ ), erythromycin (444 to $522 \mu \mathrm{g} / \mathrm{kg})$, and spyramicin $(1,106$ to $1,346 \mu \mathrm{g} / \mathrm{kg})$ were greater than EU-MRL $(50,40$, and $200 \mu \mathrm{g} / \mathrm{kg}$, respectively). Althaus et al. (2003) and Montero (2004) reported greater DL for tylosin (100 to $220 \mu \mathrm{g} / \mathrm{kg}$ ), erythromycin (700 to $980 \mu \mathrm{g} / \mathrm{kg}$ ), and spyramicin $(15,500 \mu \mathrm{g} / \mathrm{kg})$ when using the Eclipse-100ov and Delvotest-SP tests in ovine milk. As a result, BY showed a great sensitivity for macrolides compared with the abovementioned screening tests, but only tylosin could be detected at concentrations below or at the EU-MRL. Tylosin is an antibiotic developed for veterinary use with a variable activity again gram-positive and mycoplasma organisms. It is frequently used for contagious agalactia treatment in enzootic areas in case of clinical outbreaks (i.e., Mediterranean countries), and conse- quently, detection programs based on an appropriate screening test should be established.

Results obtained by using BY for tetracyclines demonstrated that this test was more sensitive for tetracycline with a DL (233 to $257 \mu \mathrm{g} / \mathrm{kg}$ ) greater than EUMRL $(100 \mu \mathrm{g} / \mathrm{kg})$ but lower than DL obtained by using Eclipse-100ov (480 $\mu \mathrm{g} / \mathrm{kg})$, Delvotest-SP $(590 \mu \mathrm{g} / \mathrm{kg})$, or BRT-AiM (6,200 $\mu \mathrm{g} / \mathrm{kg}$; Althaus et al., 2003; Montero, 2004; Molina et al., 2003). The BY test had a sensitivity similar to other methods for doxycycline (323 to 419 $\mu \mathrm{g} / \mathrm{kg}$ ), a very improved sensitivity for oxytetracycline (398 to $501 \mu \mathrm{g} / \mathrm{kg}$ ) compared with the BRT-AiM test $(5,500 \mu \mathrm{g} / \mathrm{kg}$; Molina et al., 2003), and a low sensitivity for chlortetracycline $(3,331$ to $3,989 \mu \mathrm{g} / \mathrm{kg})$. Nevertheless, the tetracycline family, and particularly chlortetracycline, showed DL clearly separate from EU-MRL $(100 \mu \mathrm{g} / \mathrm{kg})$.

The DL for sulfadimethoxine (101 to $119 \mu \mathrm{g} / \mathrm{kg}$ ) was slightly greater than EU-MRL (100 $\mu \mathrm{g} / \mathrm{kg})$. Sulfathiazole (122 to $151 \mu \mathrm{g} / \mathrm{kg}$ ), sulfamethazine (309 to $328 \mu \mathrm{g} /$ $\mathrm{kg})$, and particularly sulfanilamide (1,750 to $2,674 \mu \mathrm{g} /$ $\mathrm{kg})$ had DL greater than EU-MRL $(100 \mu \mathrm{g} / \mathrm{kg})$. The sulfonamides were better detected by BY than by other screening tests such as Eclipse-100ov (170 to $750 \mu \mathrm{g} /$ $\mathrm{kg}$ ), except for sulfanilamide, which was better detected by the Eclipse-100ov test (370 $\mu \mathrm{g} / \mathrm{kg}$; Montero, 2004). The BRT-AiM test DL for the sulfonamide family (3,200 to $6,500 \mu \mathrm{g} / \mathrm{kg}$; Molina et al., 2003) were much greater than those obtained by the BY test.

The DL for quinolones (4.7 to $71 \mathrm{mg} / \mathrm{kg}$; Table 2) were much greater than EU-MRL (30 to $100 \mu \mathrm{g} / \mathrm{kg}$ ) and similar to results reported for the Eclipse-100ov test (3.7 to $90 \mathrm{mg} / \mathrm{kg}$; Montero, 2004).

Comparing our results with those obtained by using other screening tests, it must be emphasized that there are important differences among methods for antimicrobial DL, particularly for several aminoglycosides, macrolides, and sulfonamides, despite the fact that all these methods use microbial inhibitor procedures based on inhibition of spore outgrowth of G. stearothermophilus var. calidolactis. In this sense, different performances among methods cannot be fully explained by differences in strain types used in each test (i.e., BY and Eclipse tests are based on the same strain of $G$. stearothermophilus: ATCC 10149). Thus, the concentration of organisms within individual wells and the properties of the gel or culture medium in which the organisms are placed could be important in increasing the sensitivity of the screening test, but this information is not available.

This study was carried out in individual Assaf milk samples and in midlactation. Early lactation is also an important period for an increased risk of antibiotic residues, but some screening tests can show high rates 
of false-positive outcomes in colostrum. A previous study using BY to evaluate the residue status in colostrum demonstrated a BY specificity rate of 0.966 in Assaf ewes (Linage et al., 2007). This is an increased rate compared with other screening tests used in dairy cattle (Andrew, 2001), so BY could be used in early and midlaction in dairy sheep.

\section{CONCLUSIONS}

For antimicrobial drugs whose DL were similar to those established as EU-MRL, the following values, calculated by means logistic regression, were obtained by BY: 3 to $4 \mu \mathrm{g} / \mathrm{kg}$ for penicillin G; 96 to $107 \mu \mathrm{g} / \mathrm{kg}$ for ceftiofur; 720 to $781 \mu \mathrm{g} / \mathrm{kg}$ for framycetin; 915 to 1,084 $\mu \mathrm{g} / \mathrm{kg}$ for neomycin; and 44 to $51 \mu \mathrm{g} / \mathrm{kg}$ for tylosin. In contrast, sensitivity was low or very low for the remainder of antimicrobial agents studied, although BY showed improved sensitivity compared with other screening tests studied in ovine milk. For this reason, we would recommend improvement in the sensitivity of screening tests to detect a greater number of residues of antimicrobial agents in ovine milk.

\section{ACKNOWLEDGMENTS}

This paper was developed within the Plan Nacional I+D+i: project PETRI 95-0839. OP between the University of León (Spain) and the Consortium for Ovine Promotion (CPO) in Castilla-León, Villalpando, Zamora (Spain).

\section{REFERENCES}

Allison, J. R. D. 1985. Antibiotic residues in milk. Br. Vet. J. 141:121-124.

Althaus, R., P. Molina, M. Rodríguez, and N. Fernández. 2001. Evaluation of the $\mathrm{BRT}^{\circledR}$ method for detection of $\beta$-lactam antibiotics in ewe milk. Milchwissenchaft 56:568-572.

Althaus, R. L., A. Torres, A. Montero, S. Balasch, and M. P. Molina. 2003. Detection limits of antimicrobials in ewe milk by Delvotest photometric measurements. J. Dairy Sci. 86:457-463.
Andrew, S. M. 2001. Effect of composition of colostrum and transition milk from Holstein heifers on specificity rates of antibiotic residues tests. J. Dairy Sci. 84:100-106.

Berruga, M. I., M. Yamaki, R. L. Althaus, M. P. Molina, and A. Molina. 2003. Performances of antibiotic screening tests in determining the persistence of penicillin residues in ewe's milk. J. Food Prot. 66:2097-2102.

Dewdney, J. M., L. Maes, J. P. Raynaud, F. Blanc, J. P. Scheid, T. Jackson, S. Lens, and C. Verschueren. 1991. Risk assessment of antibiotic residues of beta-lactams and macrolides in foodproducts with regard to their immunoallergic potential. Food Chem. Toxicol. 29:477-483.

European Union. 1990. Council Regulation (EEC) No. 2377/90 of 26 June 1990 laying down a Community procedure for the establishment of maximum residue limits of veterinary medical products in foodstuffs of animal origin. Off. J. L 224:1-8.

Gardner, I. A. 1997. Testing to fulfill HACCP (Hazard Analysis Critical Control Points) requirements: Principles and examples. J. Dairy Sci. 80:3453-3457.

International Dairy Federation. 1991. Detection and confirmation of inhibitors in milk and milk products. IDF Bull. No. 258. International Dairy Federation, Brussels, Belgium.

International Dairy Federation. 1999. Guidance for the standardized evaluation of microbial inhibitor tests. IDF Standard No. 183. International Dairy Federation, Brussels, Belgium.

Linage, B., A. Martínez, and C. Gonzalo. 2007. Antibiotic dry therapy with penethamate hydriodide, benethamine penicillin and framycetin sulphate in dairy ewes: Effectiveness against mammary infection and antimicrobial depletion in the postpartum period. 5 th International Symposium on the Challenge to Sheep and Goats Milk, April 2007. Alghero (Sardinia), Italy. (In press). Int. Dairy Fed., Brussels, Belgium.

Marco, J. C. 1994. Mastitis en la oveja Latxa: Epidemiología, diagnóstico y control. Doctoral thesis. Univ. Zaragoza, Spain.

Molina, M. P., R. L. Althaus, A. Molina, and N. Fernández. 2003. Antimicrobial agent detection in ewes' milk by the microbial inhibitor test brilliant reduction test-BRT AiM ${ }^{\circledR}$. Int. Dairy J. 13:821-826.

Montero, A. 2004. Aplicación de métodos microbiológicos en la detección de residuos de antimicrobianos en la leche de oveja. Doctoral thesis. Univ. Valencia, Spain.

Mourot, D., and S. Loussouarn. 1981. Sensibilité des ferments lactiques aux antibiotiques utilisés en médicine vétérinaire. Rec. Med. Vét. 157:175-177.

Ortega, C., J. P. T. M. Noordhuizen, K. D. C. Stärk, and M. V. Thrusfield. 1995. Manual de epidemiología aplicada para el veterinario clínico. European Network on Veterinary Epidemiology and Animal Health Economics (EPIDECON). Esteve Veterinaria, Barcelona, Spain.

SAS Institute. 1998. SAS User's Guide: Statistics. Release 6.12. SAS Inst., Inc., Cary, NC.

Yamaki, M., M. I. Berruga, R. L. Althaus, M. P. Molina, and A. Molina. 2004. Occurrence of antibiotic residues in milk from Manchega ewe dairy farms. J. Dairy Sci. 87:3132-3137. 